\title{
Polarized views of Quaternary ice sheets
}

\author{
D.Q. Bowen
}

DURING the past decade the major thrust in Quaternary research has been directed towards an investigation of oceanic deposits, and from such work a definitive stratigraphic framework for the entire period has emerged. At the same time, attempts have been made to correlate continental events with this unique actualistic yardstick. Hitherto only blessed with varying degrees of success, the outstanding exception has been the CLIMAP reconstruction of the Earth's surface 18,000 years ago. An essential element in this was an estimation of the extent and dimensions of the ice-sheets an input made by some of the contributors to The Last Great Ice Sheets. But although the original aim was to reconstruct the icesheets in three dimensions as a prelude to numerical modelling of the contemporary atmosphere, this had to be modified due to progressive realization that the extent and palaeoglaciology of those ice-sheets was imperfectly known.

In this handsomely produced collection of essays, complete in a case with folding maps, we have an attempt at understanding the basic parameters of the ice-sheets, divided into three general sections: Bjorn Andersen and others discuss the timing and maximum extent of ice-sheets and valley glaciers; Hollin, Schilling and Hughes employ numerical models for estimating ice-sheet and valley glacier elevations; and Denton, Hughes, Stuiver and others attempt reconstructions of ice extent and dimension between 21,000 and 17,000 years ago.

Before any such reconstruction can be made, the maximum extent and flow lines of the ice must be established. Unfortunately good stratigraphic control is rarely available, geomorphic features are often equivocal and too often the sole arbiter for control is radiocarbon dating - frequently of organic materials incorporated into glacial deposits. Furthermore, virtually no dates exist for the critical period between 35,000 and 12,000 years ago on the northern margins of the ice-sheets. Together, these factors have engendered an uncertainty, which has led to a major divergence of opinion as to the extent and timing of the maximum ice-cover in the far north.

What can be called the "minimum extent school" of thought maintains that northern and southern limits of the icesheets were out of phase: the southern maximum being attained 21,000 to 17,000 years ago, the northern maximum during
The Last Great Ice Sheets. Edited by George H. Denton and Terence J. Hughes. Pp.484 plus maps. ISBN 0-471-06006-2. (Wiley: 1981.) $£ 70.20, \$ 126.35$.

the late-Glacial or even during the early post-Glacial, a lack of synchronism attributed to a late availability of precipitation as the oceanic polar front migrated northwards at the end of the glacial stage. On the other hand, the "maximum extent school", heavily hall-marked in this book, argue that both northern and southern limits were synchronous and that a unified northern ice-complex behaved as a single dynamic entity. This view derives from Antarctic perspectives, notably from Denton and Hughes, the editors of this volume, who have worked extensively in the far south. It could, of course, be argued that theirs is a proper uniformitarian view. Yet, the Antarctic ice-sheet is polar, whereas ice-sheets of the Northern Hemisphere were primarily mid- and higher-latitude ones, for which, moreover, no analogue exists today. Furthermore, the Antarctic model relates very largely to the unstable West Antarctic ice-sheet with its fringe of floating ice-shelves.

The inferred sequence presented in the book is both novel and challenging: grounded ice-sheets would form on shallow continental shelves and inland Arctic seas, especially when surrounded by protective islands as in the Kara and Barents Seas and Queen Elizabeth Islands. Rapid ice-thickening would create icedomes, the nuclei of marine ice-sheets. Beyond these, ice-shelves would buttress the inherently unstable ice-domes, and would link the North American and Eurasian Arctic ice masses. During deglaciation a rising sea-level would free ice-shelves from bedrock underpinning points. Because they would no longer buttress the ice-domes, collapse of the domes by downdrawing followed, glacier surging occurring along troughs leading to calving bays.

But is the Antarctic perspective applicable to the Northern Hemisphere? Did marine ice-sheets actually exist? Not according to those who work in the Canadian Arctic and Spitsbergen who are intractably opposed to these views. And here it must be said that Western geologists have not had sufficient opportunity to examine cores from the Kara and Barents Seas, pronounced to be glacial deposits by their Soviet counterparts: they could yet turn out to be glacio-marine and not glacial. It could also be argued that icesheets as large and thick as those required by the "maximum extent school"' would not have responded as swiftly to climatic changes as a now increasing volume of geological evidence shows they did.

The Antarctic paradigm for northern ice-sheets is topical, innovative and above all a major challenge. It may already have some relevance in areas such as the coast of Maine, or possibly the Irish Sea. But the outlook is one of intensified debate between the two schools of thought, with the burden of proof leaning on those who subscribe to what even the editors themselves call an "outrageous hypothesis".

D.O. Bowen is Reader in Geography at The University College of Wales, Aberystwyth, and is Immediate Past President of The Quaternary Research Association.

\section{Secrets of secretion}

\section{B.L. Ginsborg}

The Electrophysiology of Gland Cells. Monographs of the Physiological Society, No.36. By O.H. Petersen. Pp.253. ISBN 0-12-553120-6. (Academic: 1981.) £20.40, $\$ 49$.

UNCHARITABLE proponents of the "important question" approach to research are apt to point out that electrical activity is not the function of gland cells. One might retort that neither is it the function of motor axons nor of muscle fibres, but this has not prevented electrical studies providing major insights into the motor system. That line of defence is, however, unnecessary for this admirable monograph which has a title more restrictive than its subject matter. True, it records and analyses the substantial efforts that have been made over the past ten years or so to understand the electrical properties and activity of gland cells, but at every turn an attempt is made to relate electrical to secretory activity. The illustrations are not confined to circuit diagrams and records of voltage and current, but include records of flow and of ion concentrations, and electron micrographs.

The diversity of approach is matched by the diversity of material: pancreas, liver, adrenal medulla and pituitary of 